Journal of Education and Vocational Research

Vol. 3, No. 11, pp. 344-352, Nov 2012 (ISSN 2221-2590)

\title{
Study on the Effectiveness of Computer Application Course to the Polytechnics Students in the Working Environment
}

\author{
Cr. Ling Ying Leh \\ Polytechnic of Kuching Sarawak, Malaysia \\ lingyingleh@gmail.com
}

\begin{abstract}
Malaysia Polytechnic Transformation Program was launched to improve the quality of vocational and technical education in Malaysia and form a quality human capital capable of increasing productivity significantly. Human capital that produced should be the ICT literacy groups and will contribute to the needs of industry. Hence, Computer Application course that offered to the students must be revised from time to time and updated content to fulfill the needs of industry. The purpose of this study is to investigate the relevance of Computer Application course to the polytechnic graduates from the perceptions view of students and employers. Review and survey involved 375 students who have completed their six months industrial training and was continue study in the final semester currently on five polytechnics which have been identified through cluster sampling and purposive sampling. In order to get the perception of the employers, convenient sampling was used in this study. The instruments used are two sets of questionnaires adapted from University Putra Malaysia, the Exit Survey for Graduating Students and Stakeholders Survey for Outcome Based Education (OBE) - Industry / Employer / Alumni developed by Professor Dato Ir. Dr. Radin Umar Radin Sohadi. The pilot test obtained the Alpha Cronbach value of 0.962 . The data was analyzed using descriptive statistics, mean, standard deviation, and percentage. Through this study, the highest mean value on attributes of the graduate attainment is derived from students' perceptions is Lifelong Learning and information management, which was 3.74. Next, the research showed the lowest mean value of 3.60 on the thinking and scientific skills approach. The findings also show that the perception of the employers on polytechnic graduates that they have the ability to apply their knowledge of computer literacy into careers with the highest mean value of 4.20 . However, only 52\% of employers give opinion that's Polytechnic graduates are able to act as a manager / leader with a mean value of 3.36. The findings also showed that $96 \%$ of employer agrees that BC101 course is relevant and fulfills market needs.
\end{abstract}

Keywords: Computer application, Graduate attainment, Working Environment

\section{Introduction}

Nowadays the change of information and technology is affecting our daily life and activity whether in the career of communication, business, agriculture, or education. We are enjoying our life every day. As an example, we are able to communicate effectively with anyone even though we are in the long distance. Education in Malaysia also goes through the transformation resulting from the development of technology. Technology has been incorporated in most curriculums so that learning can be done in anytime anywhere with the help of internet access. Due to this reason, knowledge on application computer and internet is very important for them to access and use of computer in everywhere. National Key Result Area (NKRA) was announced by our Prime Minister; Datuk Seri Najib Tun Razak on 27 July 2009. One of the key is to expand and access to quality and affordable education. Polytechnics were implementing the mission so that all the graduates well prepared with the knowledge and skills to face the challenging in international career. This is important to ensure that these graduates to meet the needs of the industry when come into their workplace. The industry was requires graduates with a variety of skills, especially the skills of 'employability'. According to Rasul, Ismail, Ismail, Rajuddin \& Rauf (2009), skills and knowledge in information and technology is the skills preferred by the employer during process of recruitment. This is because a graduates that have the basic knowledge and skills on computer is always more sensitive and caring on the society issue if compare to the people who are lack of skills of application computer. In the research study of Awang, Ismail, Hamzah, Ahmad and Uli (2008), founds that even though there is some employers who do not require workers to use computers, but they realize that the computer skills is necessary and will help their career progression in the 
future. According to the study, $60 \%$ employer says that the technology of using computer is to replace the old technique of working style. In order to face the challenges of technology in education career, department of polytechnics has built an on-line platform (online) as an alternative to expand quality education that is not limited in the class only, but also can be done in anywhere and anytime. CIDOS (Curriculum Information Document Online System) is one of the platforms that exist in all polytechnics nowadays. Through this platform lecturer can upload notes, assignments, video, and other task. Students can download the important notes from the CIDOS website. Indirectly, this requires student to have the basic computer skills to participate in this platform.

Computer literacy is a fundamental course in the learning process nowadays. Polytechnic should always enhance the skills of graduates in using of computer so that the quality of students can upgrade from time to time as mentioned by our General Director of the Department of Polytechnic Mejar (K) Hj Mohd Nor bin Yusof in his speech during 2012 New Year celebration. Undoubtedly the responsibility and challenge of the Polytechnic is greater compare to others. Anywhere, is that the graduates of the polytechnics students is being well prepare from the knowledge of technology? Ministry of Education tries to upgrade the knowledge of computer literacy in the primary and secondary school through the implementation of the computer subject and free distribution of "notebook" to the students. Yet, this method cannot be fully implemented because there are constraints that have to be faced such as lack of allocation for the construction of a computer lab at school, distribution of notebook is not comprehensive, lack of experienced teacher in the subject of computer literacy and so on. However, are the Polytechnic graduates ready to face it in terms of knowledge and technology, especially in the computer technology? According to the research by Boon and Ngatimin (2011) found that the basic computer skills among the teachers are a barrier to the use of a comprehensive computer laboratory. This is because students only expose to the simple knowledge on Microsoft word. Other than that, lack of computer is also one of the factors. Research by Shiung (2007), states that $33.3 \%$ from the students IPTA in Johor had never been exposed to the subject that related to the computer. This proved that not all the students were exposed to the subject computer when they are study in the school. This small group of students will be facing problems when the class is conducting in the type of elearning since they don't have the computer skills. Indirectly how can they finish the task that given by the teacher? Due to this, the whole polytechnic in Malaysia which is under Ministry of Higher Education was decided to implement the computer skills among the students in Semester 1 by offering the course of computer application to them. On the other hand, researchers also study the perception of the employers on the relevancy of computer application towards the working environment. Researchers also finalize the quality of the polytechnics graduates that requires by the employers.

Bunn and Stewart (1998) agree that the skill of information and technology is important to develop other base skill. According to the study of Buntat (2004), he states that knowledge in IT is one of the skills that emphasized by the industry in Malaysia. Research by De Leon \& Borchers (1998) on more than 500 employers in the manufacturing industry found that nearly $64 \%$ admitted the keyboard skills are the skills that needed by industry. Besides that, the same research also shows that almost $57 \%$ require employees who have the skills to use word processing software while $66.3 \%$ were requiring skilled in using worksheets. Polytechnics under Ministry of higher Education were decided to continue the effort done by Ministry of Education by implementing skills of computer to the entire student in Semester 1 by offering BC101 Computer Application. In order to ensure that Computer Application courses always relevant to the needs of the market, the researchers feel that there is a need to study the relevance of Computer Application course in helping them to get into the working career from the perception of students and employers. This study is expected to provide useful information to the Department of Polytechnic Education, Ministry of Higher

Education. It is to determine the relevancy of Computer Applications course that offerings to students in the polytechnic semester. In addition, this study also seen that the relevance of the course that provides to the polytechnic graduates for employment. This is necessary so that the course content is always relevant and appropriate to the needs and requirements of our market to provide polytechnic graduates right quality.

\section{Computer Application Course}

Computer Application Course with the course code BC101 is offered to all the Semester 1 students in Polytechnics except student that's under department of information technology and communication. The aim 
of the course with 1 credit unit is to well-equipped students with the knowledge and skills on the computer system neither hardware nor software. In addition, the course will also expose students to some of the application software such as word processing, spreadsheets, project management, presentation, basic multimedia, and internet. This course is conducted for 15 weeks of study in which 2 hours will be allocated for each week. It includes six titles to be completed that are (1) Computer Systems, (2) Internet, (3) Word Processing, (4) Spreadsheet, (5) Project Management and (6) Presentation and the basics of Multimedia (6). Through this course, students are given the opportunity to integrate various ICT skills that have been learned so that to accomplish the project task that assigned to them.

\section{Methodology}

The methodology of this research is divided into design of study, population and sample, research instrument, a pilot study, and data analysis. In this study, the perceptions of students and employers regarding the relevance of computer application course was collected by using survey method. Survey is done by distributing questionnaires to the students who are in sixth semester on Semester June 2012 and the employers of the industry in Malaysia. This group of students have been attended the course Computer Applications during the semester 1 and they have completed the industrial training on semester 4 . The study population consists of sixth semester students who are pursuing a diploma courses in polytechnics and employers of the industry in Malaysia. Thus, the group is said to be able to give their views on the useful of the computer knowledge while undergoing training in the industry. Descriptive statistics was used to obtain the mean value for the domain specified learning based on perceptions or views of students and employers. For the purpose of sample selection in this study, cluster sampling was used. Cluster sampling is often the most economical form of sampling. Two major sources of cost are almost always reduced with cluster sampling: listing costs and travel cost. The polytechnics in Malaysia can be categorized into five main zones, namely North Zone, Central Zone, South Zone, East Zone, and Borneo Zone. A polytechnic was randomly selected from each zone of Polytechnics. That's are Polytechnics Mu'adzam Shah (researcher) representing Northern Zone, Polytechnic Ungku Omar (PUO) in the Central Zone, Polytechnic Port Dickson (PPD) for South Zone, Polytechnic Sultan Mizan Zainal Abidin (PSMZA) represents East Zone and Polytechnic Kuching (PKS) for Zone Borneo. From the selected polytechnics, to ensure that the selected sample meets the criteria, then purposive sampling method is used to retrieve information from a specific group of students of final semester and those who have completed their industrial training. The advantages of using purposive sampling are those people who are unsuitable for the sampling study or who do not fit the bill have already been eliminated, so only the most suitable candidates remain. Also, with fewer time constraints and a more accurate subject, the costs for carrying out the sampling project are greatly reduced. In order to get the perception from the employers, convenient sampling method was used in this study. Due to the limited time, 21 employers were chosen from the industry to facilitate data collection. Convenient sampling is the selection of the sample from the population that based on how easy the samples obtained. It is an accidental sample. However, this method does not reflect the entire population of the study because it was considered biased. Therefore, these findings cannot be generalized to the whole population.

A total of 99 respondents from the POLIMAS have submitted questionnaires that contributed to $26.4 \%$ of the total respondents. Second largest contributor is came from respondents of PSMZA with 22.1\% (83 respondents), followed by a PPD of 20\% (75 respondents), PUO with 17.3\% (65 respondents) and lastly PKU represents $14.1 \%$ of the 53 respondents. A total of 375 students was took part in this study. The research instrument was in the form of structured questionnaires administered to respondents. Formation item refers to a modified questionnaire survey from University Putra Malaysia (UPM) - Exit Survey for Graduating Students and Stakeholder Survey for Outcome Based Education (OBE) - Industry/ Employer/ Alumni, which was developed by Professor Dato Ir. Dr Radin Umar Radin Sohadi whose was the Vice-Chancellor of UPM. Questionnaires distributed to the students can be divided into two parts. The first part concerned with the attainment or skills acquired by students using a 5-point Likert scale (1-Very Low, 2-Poor, 3-Fair, 4-High, 5Very High) while the second part is about the views of students on Computer Application courses. This questionnaire is answered by student based on the experience on the course of Computer Application in Polytechnics. This questionnaire is important to see whether the course of Application Computer can prepare the polytechnic graduates to work in the industry. This questionnaire seeks the opinion from the employers on the graduates through their experience, observation, or perception on each attribute. For the 
questionnaires to the employers, it is divided into three parts. Part A is on the employer information. Part B is concerned with the view or perception of employers on skills available to fresh graduates. This section uses 5-point Likert scale (1-Strongly Disagree, 2-Disagree, 3-Not Sure, 4-Agree, 5-Strongly Agree). Section C is intended to view employers on this Computer Application courses. A pilot study was conducted on 38 students who was in the sixth semester and completed their industry training at Polytechnic Kuching Sarawak. Alpha Cronbach value that obtained through the pilot study was 0.962 . This value proves that the reliability of the questionnaire is high.

\section{Results and Discussion}

Employers' Perception on the Course of Computer Application: Table 1 shows the total number, percentage, mean, and standard deviation for the statements of employers' perception on polytechnic graduates. Based on the study, almost $83 \%$ employers agree that polytechnics graduate was playing a role in group activity have a mean value of 3.75. As we know the aspect of teamwork is very important. Graduates suppose be prepared well for a culture that build on sharing and collaboration. Graduates should learn socializing with their peers and get to know them. Peers' support and help are valuable especially when you go through the painful periods at work. In addition, the willingness and desire to take on challenges will be noted by employers. However $20 \%$ of the employers do not agree that polytechnic graduates are able to facing the challenges in their career with a mean value of 3.80. This is probably because most of the polytechnics graduates does not choosing the industry according to their interest. As we know only passion and commitment can reward and drive the graduates to long term success in the career. Graduates should be prepared for working under tight deadlines and accompanied with high expectations. Due to this, polytechnic graduates should be well prepared for competitive workplace. The finding of Table 1 show that the mean value as high as 4.20 in which students are able to apply the knowledge of computer literacy on their tasks. Through this research, the researchers also found that about $88 \%$ of the employers agree that graduates are able to design and conducts task practically in which the mean value of 3.96. The polytechnics graduate should try their best in any projects that assigned to them. This is because the knowledge and experienced that they gain will be well worth it although they are long hours and hard work. Almost $52 \%$ employers agree that graduates of polytechnics are able to function as leader or manager with the mean value of 3.36 . Nowadays, leadership potential is one of the most highly price assets. Employers look for assertiveness, confidence, initiative, and a "winning mentality". From the research, there is $20 \%$ of employers complain that polytechnics graduate didn't have the ability to use the necessary skills, techniques and tools with a mean value of 3.72 . The findings have detected that there is $28 \%$ employer does not agree with the ability of the polytechnics students on statements identify, formulate and provide creative, innovative and solutions to the problems with a mean value of 3.60. Students need to learn and gain much experience in the industry and at the same time, learn more and reflect on their own strength and weakness. Only after this, graduates know and able to position themselves.

People relationship is one of the important elements for success; hence communication skills have to be built. The findings show that $30 \%$ employer complains that most of the polytechnics students do not have the ability to communicate effectively with a mean value of 3.71 . This statement should be bear in mind since the skill of the communication has been determined as one of the most important criteria during process interview by over 100 companies according to the study report of the Malaysia's 100 leading graduate's employers 2011. According to the research report of Job Street on November 2011, there is 56\% out of 1830 graduates was failed in the English communication. Almost $40 \%$ of the employers agree that most of the graduates do not have the knowledge of the contemporary issues. The mean value of 3.60 implies that students should be enjoying, learning, and dealing with new issues every day. This will help the students to adapt new environment. Next, there is roughly $24 \%$ employers disagree with the ability of graduate in analysis and interpret data. The mean value of 3.80 shows that the students should have a strong fundamental knowledge in the field and be creative when facing never-ending challenges. They should learn to study the project assigned to them deeper and be strong. The researchers also found that $80 \%$ of the employer agrees with the statements "Understanding of professionals and ethical responsibility". This is because if the students have a good work ethic and enjoy the work, they are always being welcome in any job role. The data also shows that $76 \%$ employers agree with the recognition of the need and ability to engage in lifelong learning's. The findings of Table 2 show the fulfillment of theory and concept of the Application 
Computer based on the employers' perception. There is 56\% of the employers agree that the course BC101 fulfill the basic theories required in the related discipline. This can be seen where majority of the employer was fully agree with the criteria of the course BC101. Researchers found that almost $71 \%$ of the employees fully agreed and $29.2 \%$ is partially agreed that the course fulfill the criteria of basic theory. Other than that there is only $58.3 \%$ of the employers fully agree that the course fulfill the criteria of current concept while almost 38\% disagree on it. There are $75 \%$ of the employers saying that the course fulfills the criteria of the use of IT. However, only 58\% employers agree that Application Computer fulfill the criteria of market/industry survey. From Table 3, 96\% and $92 \%$ of the employers are agreeing that the theory use in the course BC101 is relevant to the course situation and the course contributes to the strength of the Polytechnic program respectively. However $12 \%$ of the employers are complaining that there is some irrelevant topic in the course of BC101. Based on the feedbacks received, the irrelevant topics referred to Computer System, Word Processor, and Internet.

Students' Perception on the Course of Computer Application: The findings of Table 4 show that only $48 \%$ of the graduates show their willingness to work under tough deadlines and pressure with the mean value of 3.49. $72 \%$ of the students have highly practiced the teamwork skills in their daily activities with the mean value of 3.96. Working under a team will be maximize your learning from each other and enhance the career opportunity. From the data, there is almost $61 \%$ with the mean value of 3.74 from the graduates, have the ability to manage the time effectively and working independently. There is $46 \%$ students admit that they didn't have the ability to do multi-tasking in the same time. As an overall, the management skills and entrepreneurship received the mean value of 3.72 which is consider as an average level. Graduates should also possess excellent communication skills. It will make them a winning edge if they are able to write and speak good English. The study shows that $71 \%$ of the students can communicate well in Bahasa Melayu with the mean value of 3.99 but only $52 \%$ students can communicate well by using the English language if compare to Malay language. The graduates must be able to communicate fluently in both languages; to elaborate and articulate as well as answer questions. This goes for both reading and writing. The researchers found that there is $52.8 \%$ and $52.7 \%$ of the Polytechnic graduates can interact socially in a variety of situations and writing effectively for different purposes with the mean value of 3.55 and 3.56 respectively. Almost $46 \%$ students saying they are less confident on practicing good and quality communication skills for job interviews with the mean value of 3.62. Nowadays graduates need to present themselves well during the interview session if they want to get good jobs. This is because they need to be able to compete with other peoples who seeking employments as well. As an overall, statements of communication skills obtained the mean value of 3.66 in this study. The research also shows that almost $40 \%$ of the graduates cannot use the word processor effectively. This shows with the mean of 3.73. Task on analysis data is one of the problems that they cannot solve. On the same time they also were facing difficulty to prepare the presentation task by using multimedia. The mean is as high as 3.71 and 3.70 respectively. Almost $55 \%$ students say that they can use variety of broadcasting equipments. The findings also show that almost half of the respondents don't use the internet for research especially when they come to their interview. In order to be success in the interview, graduates need to do some study about the career information. For example, those candidates who would like to attend the interview for a bank, the candidate needs to know the bank's strategy and read the paper or iPad news app every day. The candidate needs to know the latest news in the industry and bank. The mean value for technical, practical or psychomotor skills is as high as 3.68 .

Next, almost $63 \%$ graduate says that they have the positive work ethics and attitudes with the mean value of 3.76. This is followed by $62 \%$ graduate has a high commitment to the professionalism with a mean 3.74 . Anywhere there is still $41 \%$ of the graduate deny on the statement "Commitment to social and cultural values". Research also found that $40.5 \%$ and $4.8 \%$ of the graduate having low level on the awareness of current social issue. Almost 55\% of the graduates agree that they are practicing ethics and communication in their working environment. As an overall, professionalism, values, attitude, and ethics statements get the mean value of 3.69. Preferably knowledge and skills within the role the graduate is going to be in. The industry is seeking people who are striving for excellence, and have strong analytical, communication and leadership skills. The findings shows that $54 \%$ graduate can analyze the critical problems with a mean of 3.51 while almost $53 \%$ of them say that they can identify the alternative to solve the problems with a mean of 3.60. They are $63.2 \%$ and $52 \%$ graduate have the ability to think creative and critic with a mean of 3.73 and 3.58 each. Overall, the thinking and science skills approach obtained the mean value of 3.60 . Almost $60 \%$ of 
graduate says that they are able to maintain a good level of ICT skills with a mean of 3.80 while $60.3 \%$ of that decided to further study after grade. Through this research, the researchers also found that almost $60 \%$ of graduate says that they seek for more information with their own initiative in order to update and upgrade themselves with the mean value of 3.72. Graduates need to do some research based on their interest to decide what they want and work hard for it. Anyway, it is good to see majority of the graduates planning to further their studies with the mean value of 3.70. There will always be programs available to assist graduates; however, at the end of the day, graduates have to take the charge of their own career. Overall, the lifelong learning and information management received the mean value of 3.74. From Table 4, it shows the mean value of 3.66 shows that the graduates are able to integrate different areas of knowledge at a different level. More than half of the respondents know the method of research in order to update themselves with the most current knowledge. This is showing with the mean of 3.63. Anyway, all things are being equal. Every graduate would have similar knowledge in terms of what they have learnt in polytechnic. The most important factors, is the attitude. In addition, the finding of the mean value of 3.73 shows graduates with high personal integrity. There is a mean value of 3.72 shows graduates having high social responsibilities. However, there is $43 \%$ graduates have low public relation skills with the mean value of 3.66. Thus, there is a need to build a strong relationship with people. Thus, the social skills and sense of responsibility with the mean value as high as 3.69 is at average level.

\section{Conclusion}

The employability of Polytechnic graduates, especially the fresh graduates, is a continuing concern for many of us. In the context of Malaysia, we have thousands of Polytechnic graduates that will join the workforce annually, finding employment either locally or abroad. It is a survey data of our government that the number of unemployed Polytechnic graduates within the country is around $34.2 \%$ in 2010 . All the curriculum content for all the courses prepared a good path for the students. However, we are facing a rapidly changing world in which our graduates have to operate. In order to help the students, the course content and learning design must be fulfill to the needs of the market to improve the employability. One of the features is to provide learning that reflects the environment in which the graduate will ultimately work. If the graduates want to be an engineer, then the curriculum should provide learning opportunities that mirror the world of the engineer. This will involve both the professional bodies and employers who should provide context and examples for the students to work on. Also, the support staffs need to be involved as well. Remember the greatest success occurs in areas where all the key stakeholders work together to develop the students. Graduates clearly need the skills and knowledge to survive today. What we hope to achieve are the graduates with the ability to continually develop themselves and to improve their skills and knowledge as they need to. We want the lifelong learners who are able to adapt to a changing environment.

\section{References}

Rasul, S. M., Ismail, Y. M., Ismail, N., Rajuddin, R. \& Rauf, A. R. (2009). Aspek Kemahiran 'Employability' Yang Dikehendaki Majikan Industri Pembuatan Masa Kini. Jurnal Pendidikan Malaysia, 34(2), 67-79.

Awang, H. A., Ismail, R., Hamzah, A., Ahmad, A. \& Uli, U. (2008). Kompetensi Tenaga Kerja: Keseimbangan Antara Tuntutan Majikan \& Penguasaan Pelatih. Jurnal Pembangunan Belia Malaysia, 1, 135 - 164.

Boon, Y. \& Ngatimin, S. (2011). Penggunaan Makmal Komputer Dalam Kalangan Guru-guru Sekolah Kebangsaan Zon Jementah, Daerah Segamat Dalam Pengajaran \& Pembelajaran: Satu Tinjauan. Journal of Technical, Vocational \& Engineering Education, 3, 132 - 147.

Shing, K. T. (2007). Kajian Mengenai Penggunaan E-Pembelajaran Di Kalangan Pelajar Jurusan Pendidikan Teknologi \& Vokasional Di IPTA Negeri Johor. Tesis Ijazah Sarjana. Universiti Teknologi Malaysia.

Bunn, C. P. \& Stewart, L. D. (1998). Perceptions of Technical Committee Members Regarding the Adoption of Skill Standards in Vocational Education Programs. Journal of Vocational and Technical Eduation, 14, 7 $-17$.

Buntat, Y. (2004). Integrasi Kemahiran 'Employability' Dalam Program Pendidikan Vokasional Pertanian \& Industri Di Malaysia. Disertasi Ph.D. Universiti Teknologi Malaysia.

De Leon, E. J. \& Borchers, E. R. (1998). High School Graduate Employment Trends and The Skills Graduates Need to Enter Texas Manufacturing Industries. Journal of Vocational and Technical Eduation, 15(2). 


\section{Appendix}

Table 1: Perception of Employers on Polytechnic Graduates

\begin{tabular}{|c|c|c|c|c|c|c|c|c|}
\hline No. & Statement & $\begin{array}{l}\text { Strongly } \\
\text { Disagree } \\
\text { (1) }\end{array}$ & $\begin{array}{l}\text { Disagree } \\
(2)\end{array}$ & $\begin{array}{l}\text { Not } \\
\text { Sure } \\
(3)\end{array}$ & $\begin{array}{l}\text { Agree } \\
(4)\end{array}$ & $\begin{array}{l}\text { Strongly } \\
\text { Agree } \\
\text { (5) }\end{array}$ & Mean & SD \\
\hline \multirow[t]{2}{*}{1} & Ability to apply knowledge of & 0 & 0 & 0 & 20 & 5 & 4.20 & .408 \\
\hline & computer literacy. & 0.0 & 0.0 & 0.0 & 80.0 & 20.0 & & \\
\hline \multirow[t]{2}{*}{2} & Ability to design and conduct & 0 & 1 & 2 & 19 & 3 & 3.96 & .611 \\
\hline & tasks practically. & 0.0 & 4.0 & 8.0 & 76.0 & 12.0 & & \\
\hline \multirow[t]{2}{*}{3} & Ability to analyze and interpret & 0 & 1 & 5 & 17 & 2 & 3.80 & .645 \\
\hline & data. & 0.0 & 4.0 & 20.0 & 68.0 & 8.0 & & \\
\hline \multirow[t]{2}{*}{4} & Ability to function effectively as & 1 & 1 & 2 & 19 & 1 & 3.75 & .794 \\
\hline & an individual in a group. & 4.2 & 4.2 & 8.3 & 79.2 & 4.2 & & \\
\hline \multirow[t]{2}{*}{5} & Ability to function as a leader or & 2 & 2 & 8 & 11 & 2 & 3.36 & 1.036 \\
\hline & manager. & 8.0 & 8.0 & 32.0 & 44.0 & 8.0 & & \\
\hline \multirow[t]{2}{*}{6} & Ability to identify, formulate and & 1 & 1 & 5 & 18 & 0 & 3.60 & .764 \\
\hline & $\begin{array}{l}\text { provide creative/ innovative/ } \\
\text { effective solution to the problem. }\end{array}$ & 4.0 & 4.0 & 20.0 & 72.0 & 0.0 & & \\
\hline \multirow[t]{2}{*}{7} & Understanding of professional & 0 & 2 & 3 & 20 & 0 & 3.72 & .614 \\
\hline & and ethical responsibility. & 0.0 & 8.0 & 12.0 & 80.0 & 0.0 & & \\
\hline \multirow[t]{2}{*}{8} & Ability to communicate & 0 & 2 & 5 & 15 & 2 & 3.71 & .751 \\
\hline & effectively. & 0.0 & 8.3 & 20.8 & 62.5 & 8.3 & & \\
\hline \multirow[t]{2}{*}{9} & Recognition of the need for and & 0 & 2 & 4 & 18 & 1 & 3.72 & .678 \\
\hline & $\begin{array}{l}\text { ability to engage in lifelong } \\
\text { learning. }\end{array}$ & 0.0 & 8.0 & 16.0 & 72.0 & 4.0 & & \\
\hline \multirow[t]{2}{*}{10} & Knowledge of contemporary & 0 & 1 & 9 & 14 & 1 & 3.60 & .645 \\
\hline & issues. & 0.0 & 4.0 & 36.0 & 56.0 & 4.0 & & \\
\hline \multirow[t]{2}{*}{11} & Ability to use necessary skills, & 1 & 1 & 3 & 19 & 1 & 3.72 & .792 \\
\hline & techniques and tools. & 4.0 & 4.0 & 12.0 & 76.0 & 4.0 & & \\
\hline \multirow[t]{2}{*}{12} & Ability to meet challenges. & 1 & 1 & 3 & 17 & 3 & 3.80 & .866 \\
\hline & & 4.0 & 4.0 & 12.0 & 68.0 & 12.0 & & \\
\hline Mean & & & & & & & 3.78 & .414 \\
\hline
\end{tabular}

$\mathrm{N}=25$

Table 2: Fulfillment of Theory and Concept of the Course

\begin{tabular}{|c|c|c|c|c|}
\hline No. & Statement & Fully & Partially & None \\
\hline \multirow[t]{2}{*}{1} & Does the course BC101 fulfill the basic theories required in the related & 14 & 9 & 2 \\
\hline & discipline? & 56.0 & 36.0 & 8.0 \\
\hline \multicolumn{5}{|c|}{ State whether the course BC101 fulfills these criteria: } \\
\hline \multirow[t]{2}{*}{2} & Basic Theory & 17 & 7 & 0 \\
\hline & & 70.8 & 29.2 & 0.0 \\
\hline \multirow[t]{2}{*}{3} & Current Concept & 14 & 9 & 1 \\
\hline & & 58.3 & 37.5 & 4.2 \\
\hline \multirow[t]{2}{*}{4} & Use of IT & 18 & 6 & 0 \\
\hline & & 75.0 & 25.0 & 0.0 \\
\hline \multirow[t]{2}{*}{5} & Market / Industry Relevant & 14 & 10 & 0 \\
\hline & & 58.3 & 41.7 & 0.0 \\
\hline
\end{tabular}

$\mathrm{N}=25$

Table 3: The Relevance of the Course

\begin{tabular}{|c|c|c|c|}
\hline No. & Statement & Yes & No \\
\hline \multirow[t]{2}{*}{1} & Are the theories used in the course BC101 relevant to the current situation? & 24 & 1 \\
\hline & & 96.0 & 4.0 \\
\hline \multirow[t]{2}{*}{2} & Does the course BC101 contribute to the strength of the Polytechnic program? & 23 & 2 \\
\hline & & 92.0 & 8.0 \\
\hline \multirow[t]{2}{*}{3} & Is there any topic(s) in course BC101 that is not relevant in the Polytechnic program? & 3 & 21 \\
\hline & & 12.0 & 84.0 \\
\hline
\end{tabular}

$\mathrm{N}=25$ 
Table 4: Students' Perception on the Attainment of Graduate Attributes

\begin{tabular}{|c|c|c|c|c|c|c|c|c|}
\hline No. & Statement & $\begin{array}{l}\text { Very } \\
\text { Low } \\
\text { (1) }\end{array}$ & $\begin{array}{l}\text { Low } \\
(2)\end{array}$ & $\begin{array}{l}\text { Medium } \\
\text { (3) }\end{array}$ & $\begin{array}{l}\text { High } \\
\text { (4) }\end{array}$ & $\begin{array}{l}\text { Very } \\
\text { High } \\
\text { (5) }\end{array}$ & Mean & SD \\
\hline \multicolumn{9}{|c|}{ Lifelong learning and information management } \\
\hline \multirow[t]{2}{*}{1} & Planning to further my studies. & 5 & 12 & 132 & 166 & 60 & 3.70 & .821 \\
\hline & & 1.3 & 3.2 & 35.2 & 44.3 & 16.0 & & \\
\hline \multirow[t]{2}{*}{2} & Seeking out information to keep myself & 1 & 9 & 142 & 165 & 58 & 3.72 & .759 \\
\hline & informed. & 0.3 & 2.4 & 37.9 & 44.0 & 15.5 & & \\
\hline \multirow[t]{3}{*}{3} & Maintain my ICT skills. & 1 & 12 & 124 & 163 & 75 & 3.80 & .802 \\
\hline & & 0.3 & 3.2 & 33.1 & 43.5 & 20.0 & & \\
\hline & & & & & & & 3.74 & .657 \\
\hline \multicolumn{9}{|c|}{ Communication Skills } \\
\hline \multirow[t]{2}{*}{4} & Communicating skills for job interviews. & 0 & 26 & 144 & 148 & 55 & 3.62 & .819 \\
\hline & & 0.0 & 7.0 & 38.6 & 39.7 & 14.7 & & \\
\hline \multirow[t]{2}{*}{5} & Interacting socially in a variety of situations. & 0 & 25 & 151 & 162 & 35 & 3.55 & .755 \\
\hline & & 0.0 & 6.7 & 40.5 & 43.4 & 9.4 & & \\
\hline \multirow[t]{2}{*}{6} & Writing effectively for different purposes. & 1 & 28 & 147 & 153 & 42 & 3.56 & .801 \\
\hline & & 0.3 & 7.5 & 39.6 & 41.2 & 11.3 & & \\
\hline \multirow[t]{2}{*}{7} & Communicating in Bahasa Melayu. & 0 & 12 & 97 & 146 & 118 & 3.99 & .841 \\
\hline & & 0.0 & 3.2 & 26.0 & 39.1 & 31.6 & & \\
\hline \multirow[t]{3}{*}{8} & Communicating in English. & 1 & 31 & 147 & 138 & 56 & 3.58 & .853 \\
\hline & & 0.3 & 8.3 & 39.4 & 37.0 & 15.0 & & \\
\hline & & & & & & & 3.66 & .604 \\
\hline \multicolumn{9}{|c|}{ Thinking And Scientific Skills Approach } \\
\hline \multirow[t]{2}{*}{9} & Analyzing problems critically. & 0 & 26 & 144 & 148 & 55 & 3.51 & .777 \\
\hline & & 0.0 & 7.0 & 38.6 & 39.7 & 14.7 & & \\
\hline \multirow[t]{2}{*}{10} & Evaluating range solutions to solve problems. & 0 & 17 & 158 & 155 & 43 & 3.60 & .750 \\
\hline & & 0.0 & 4.6 & 42.4 & 41.6 & 11.5 & & \\
\hline \multirow[t]{2}{*}{11} & Thinking creatively. & 1 & 21 & 116 & 178 & 59 & 3.73 & .801 \\
\hline & & 0.3 & 5.6 & 30.9 & 47.5 & 15.7 & & \\
\hline \multirow[t]{3}{*}{12} & Thinking critically. & 2 & 28 & 149 & 138 & 56 & 3.58 & .853 \\
\hline & & 0.5 & 7.5 & 39.9 & 37.0 & 15.0 & & \\
\hline & & & & & & & 3.60 & .675 \\
\hline \multicolumn{9}{|c|}{ Management Skills and Entrepreneurship } \\
\hline \multirow[t]{2}{*}{13} & Managing time effectively. & 1 & 15 & 125 & 174 & 60 & 3.74 & .781 \\
\hline & & 0.3 & 4.0 & 33.3 & 46.4 & 16.0 & & \\
\hline 14 & Working independently. & 0 & 16 & 133 & 156 & 69 & 3.74 & .804 \\
\hline & & 0.0 & 4.3 & 35.6 & 41.7 & 18.4 & & \\
\hline 15 & Working under pressure. & 5 & 29 & 161 & 137 & 43 & 3.49 & .846 \\
\hline & & 1.3 & 7.7 & 42.9 & 36.5 & 11.5 & & \\
\hline 16 & Multi-tasking. & 0 & 15 & 158 & 145 & 56 & 3.65 & .781 \\
\hline & & 0.0 & 4.0 & 42.1 & 38.7 & 14.9 & & \\
\hline 17 & Teamwork. & 1 & 14 & 88 & 165 & 105 & 3.96 & .832 \\
\hline & & 0.3 & 3.8 & 23.6 & 44.2 & 28.2 & & \\
\hline & & & & & & & 3.72 & .621 \\
\hline Tecl & ical / Practical / Psychomotor Skills & & & & & & & \\
\hline 18 & Using a Word Processor. & 1 & 22 & 123 & 156 & 71 & 3.73 & .844 \\
\hline & & 0.3 & 5.9 & 33.0 & 41.8 & 19.0 & & \\
\hline 19 & Analyzing data using the computer. & 1 & 19 & 134 & 153 & 67 & 3.71 & .827 \\
\hline & & 0.3 & 5.1 & 35.8 & 40.9 & 17.9 & & \\
\hline 20 & Designing multimedia presentations. & 2 & 21 & 132 & 152 & 68 & 3.70 & .847 \\
\hline & & 0.5 & 5.6 & 35.2 & 40.5 & 18.1 & & \\
\hline 21 & Conducting small research projects. & 1 & 28 & 135 & 155 & 55 & 3.63 & .834 \\
\hline & & 0.3 & 7.5 & 41.4 & 41.4 & 14.7 & & \\
\hline 22 & Using variety of broadcasting equipment. & 2 & 22 & 146 & 147 & 56 & 3.62 & .829 \\
\hline & & 0.5 & 5.9 & 39.1 & 39.4 & 15.0 & & \\
\hline & & & & & & & 3.68 & .684 \\
\hline
\end{tabular}




\begin{tabular}{|c|c|c|c|c|c|c|c|c|}
\hline No. & Statement & $\begin{array}{l}\text { Very Low } \\
\text { (1) }\end{array}$ & $\begin{array}{l}\text { Low } \\
(2)\end{array}$ & $\begin{array}{l}\text { Medium } \\
\text { (3) }\end{array}$ & $\begin{array}{l}\text { High } \\
(4)\end{array}$ & $\begin{array}{l}\text { Very } \\
\text { High } \\
(5)\end{array}$ & Mean & SD \\
\hline \multicolumn{9}{|c|}{ Knowledge } \\
\hline \multirow[t]{2}{*}{23} & language/ & 3 & 27 & 137 & 148 & 60 & 3.63 & .865 \\
\hline & literature/communication. & 0.8 & 7.2 & 36.5 & 39.5 & 16.0 & & \\
\hline \multirow[t]{2}{*}{24} & Language and culture. & 4 & 22 & 152 & 138 & 59 & 3.60 & .859 \\
\hline & & 1.1 & 5.9 & 40.5 & 36.8 & 15.7 & & \\
\hline \multirow[t]{2}{*}{25} & Translation. & 2 & 26 & 141 & 140 & 64 & 3.64 & .865 \\
\hline & & 0.5 & 7.0 & 37.8 & 37.5 & 17.2 & & \\
\hline \multirow[t]{2}{*}{26} & Integration of different areas of & 0 & 21 & 143 & 151 & 57 & 3.66 & .804 \\
\hline & knowledge. & 0.0 & 5.6 & 38.4 & 40.6 & 15.3 & & \\
\hline \multirow[t]{3}{*}{27} & Research methods. & 3 & 21 & 144 & 151 & 55 & 3.63 & .831 \\
\hline & & 0.8 & 5.6 & 38.5 & 40.4 & 14.7 & & \\
\hline & & & & & & & 3.63 & .701 \\
\hline \multicolumn{9}{|c|}{ Social Skills and Sense of Responsibility } \\
\hline \multirow[t]{2}{*}{28} & Intellectual properties. & 3 & 19 & 136 & 169 & 47 & 3.64 & .796 \\
\hline & & 0.8 & 5.1 & 36.4 & 45.2 & 12.6 & & \\
\hline \multirow[t]{2}{*}{29} & Communication skills. & 0 & 24 & 124 & 170 & 57 & 3.69 & .804 \\
\hline & & 0.0 & 6.4 & 33.1 & 45.3 & 15.2 & & \\
\hline \multirow[t]{2}{*}{30} & Personal integrity. & 0 & 15 & 130 & 170 & 60 & 3.73 & .773 \\
\hline & & 0.0 & 4.0 & 34.7 & 45.3 & 16.0 & & \\
\hline \multirow[t]{2}{*}{31} & Public relations skills. & 4 & 15 & 142 & 157 & 56 & 3.66 & .819 \\
\hline & & 1.1 & 4.0 & 38.0 & 42.0 & 15.0 & & \\
\hline \multirow[t]{3}{*}{32} & Social responsibilities. & 3 & 15 & 129 & 166 & 62 & 3.72 & .814 \\
\hline & & 0.8 & 4.0 & 34.4 & 44.3 & 16.5 & & \\
\hline & & & & & & & 3.69 & .661 \\
\hline \multicolumn{9}{|c|}{ Professionalism, Values, Attitudes and Ethics } \\
\hline \multirow[t]{2}{*}{33} & Ethics and communication. & 0 & 24 & 144 & 160 & 47 & 3.61 & .786 \\
\hline & & 0.0 & 6.4 & 38.4 & 42.7 & 12.5 & & \\
\hline \multirow[t]{2}{*}{34} & Awareness of current social issues. & 1 & 18 & 152 & 154 & 50 & 3.62 & .784 \\
\hline & & 0.3 & 4.8 & 40.5 & 41.1 & 13.3 & & \\
\hline \multirow[t]{2}{*}{35} & Positive work ethics and attitudes. & 0 & 17 & 125 & 163 & 70 & 3.76 & .804 \\
\hline & & 0.0 & 4.5 & 33.3 & 43.5 & 18.7 & & \\
\hline \multirow[t]{2}{*}{36} & Commitment to professionalism. & 0 & 18 & 124 & 169 & 63 & 3.74 & .792 \\
\hline & & 0.0 & 4.8 & 33.2 & 45.2 & 16.8 & & \\
\hline \multirow[t]{3}{*}{37} & Commitment to social and cultural & 2 & 13 & 137 & 163 & 59 & 3.71 & .791 \\
\hline & values. & 0.5 & 3.5 & 36.6 & 43.6 & 15.8 & & \\
\hline & & & & & & & 3.69 & .655 \\
\hline
\end{tabular}

$\mathrm{N}=375$ 